\title{
PSYCHE
}

VOL. XLI

SEPTEMBER 1934

No. 3

\section{JOHN MERTON ALDRICH}

By A. L. MELANDER

On May 27, 1934, with the passing of John Merton Aldrich, the nation's greatest accumulation of dipterological information has ceased to be. Easily the leader in this branch of zoölogy, Aldrich will be missed, and there is no one in line who is prepared to continue where he left off.

At the age of sixty-eight, Aldrich still counted on several more years of productive work. His mind was as keen as ever, and physically he had no intimation until two weeks before the end that an abrupt catabolic derangement was to close his life. He had even completed plans to start early in June on another of his biennial collecting trips to the Pacific Coast.

Aldrich was born on January 28, 1866, in Olmstead County, Minnesota. He attended school at Rochester, near by, and in 1888 completed the course for the B. A. degree at South Dakota State College. In 1889-1890, he studied under Professor A. J. Cook at the Michigan State College, and in 1891 received the degree of M. S. from South Dakota State College. Leaving an assistantship at Scuth Dakota in 1892, he went to the University of Kansas in order to study with Professor S. W. Williston, and was awarded another degree of M. S. in 1893.

In 1893 the new University of Idaho opened, and Aldrich was selected to found its Department of Zoölogy. He married Ellen Roe of Brookings, South Dakota, and moved to Moscow. The loss of his wife and infant son four years later caused him to plunge most deeply into his dipterological work, and he began his card catalogue of the literature on Diptera, a project to which he contributed almost daily 
until his last illness. By 1905, when this catalogue had reached publication size and was about ready for submission to the Smithsonian Institution, Aldrich married Della Smith of Moscow, Idaho, and securing sabbatical leave of absence from Idaho went to Stanford University for a year. His Ph. D. degree was awarded by Stanford in 1906. Fortunately Aldrich had moved his library and collection of Diptera to his father's house because during his absence the University of Idaho burned to the ground.

Aldrich always regarded Moscow, Idaho, as home. $\mathrm{He}$ had built a beautiful house at the edge of the University campus facing Moscow Mountain, his best beloved collecting ground, and there had established his library and collection. He had every prospect of continuing his useful work at Idaho, when suddenly after twenty years of service as its most eminent professor his connection with the University of Idaho was terminated. It is unnecessary now to reopen the sorry case and discuss the vagaries of an incompetent administration other than to recall that those of us who knew the situation well regarded the dismissal as an outrageous and unwarranted interference. Aldrich's ashes have been returned to Moscow, Idaho, and placed beside his first wife and his only child.

Idaho's self-inflicted loss proved to be the nation's gain. Dr. Howard immediately appointed Aldrich to the Bureau of Entomology, and for the next five years he was stationed at Lafayette, Indiana, to investigate life-histories of Oscinidæ and other Diptera affecting cereal crops. The death of Frederick Knab in 1918 made it necessary to transfer Aldrich to the National Museum, where he was appointed Custodian of Diptera and Associate Curator.

In 1928 Aldrich presented to the National Museum his personal collection of Diptera, numbering 45,000 specimens and 4,000 named species. With this he donated the unique and extensive card catalogue of Diptera. This index is the only source of information on all the literature of all the American Diptera, and with its cross references to synonymy is invaluable to all workers. It brings the Aldrich catalogue of 1905 to date. His library is the most complete assemblage of books and articles on Diptera, and de- 


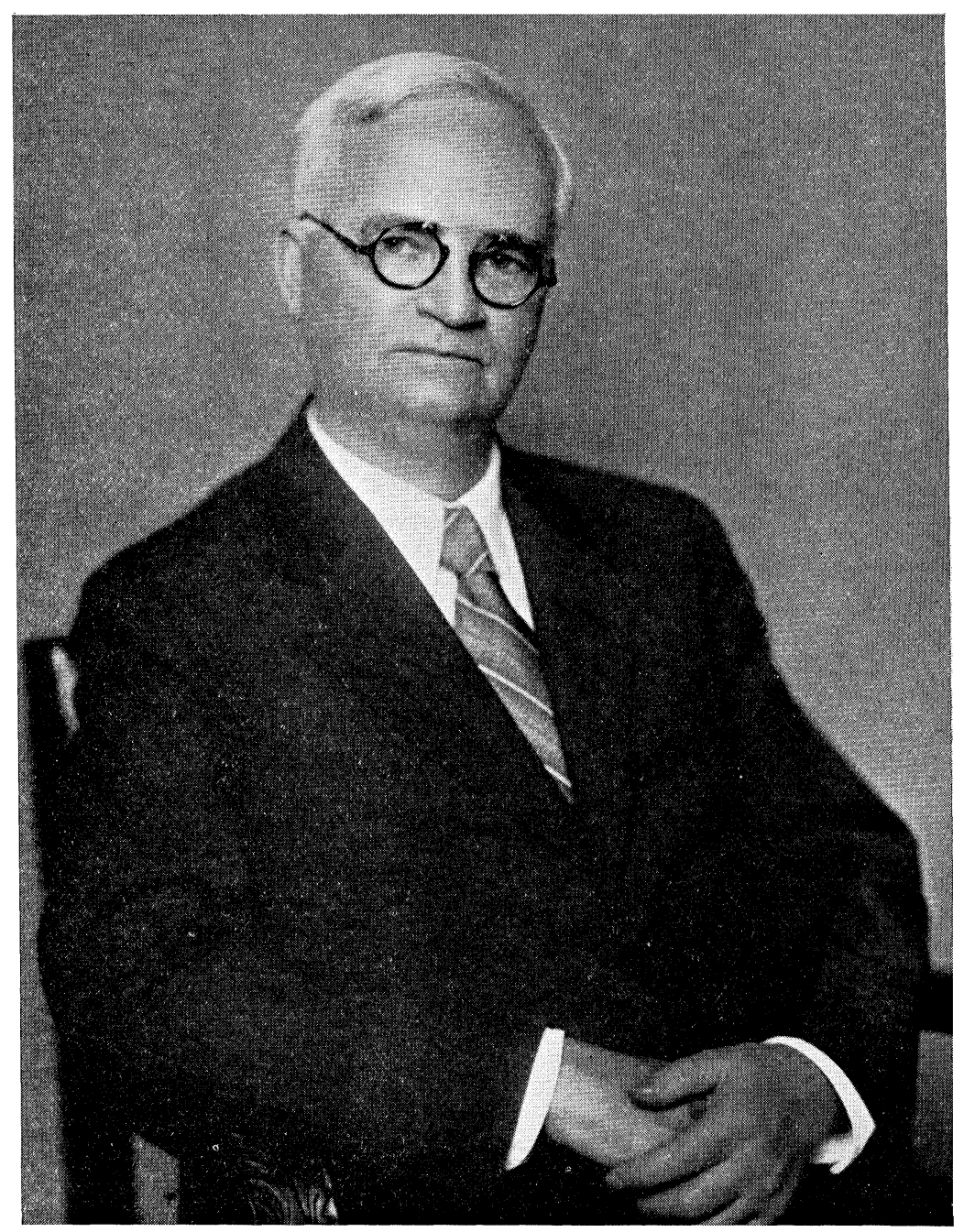

JOHN MERTON ALDRICH

$1866-1934$ 
servedly should be acquired by the National Museum to complement the collection and index.

Aldrich always generously shared his library, records, specimens, and information. Most present day dipterists owe more to him than their printed words of thanks can imply. Beyond the tremendous wealth of specialized information he held regarding the Diptera he was versatile in many lines. He was devotedly interested in the All Souls' Unitarian Church in Washington, of which he was a trustee, and conducted classes in religious history and education. $\mathrm{He}$ was keenly interested in politics and daily followed the doings of Congress. He was one of the organizers of the Thomas Say Foundation and served as editor from 1916 to 1931. He was secretary-treasurer of the Entomological Socity of America from 1915 to 1920, and President in 1921. In 1926 he was President of the Washington Entomological Society.

Aldrich had a remarkable gift of locating rare species on his collecting trips. His more extensive journeys included Utah and California, 1911; Alaska, 1921; Guatemala, 1926, and Sweden, 1930. He was meticulously careful in mounting specimens, in arranging the Museum collection, and in entering the records in his great index. His diary has daily entries for some fifty years, not merely a line or two, but a careful description of the happenings that befall an eminent man.

The accompanying bibliography, transcribed from the card index by his secretary, Mrs. Willis, gives his publications in chronological order. Outstanding in the list is the catalogue. This monumental work stimulated so many publications on the Diptera that its very importance in the progress of American entomology led to its rapid obsolescence. Would that its author could have been spared a few more years to give to all the codified information that he alone possessed. We regret his passing, but are thankful that such a man has lived and has been enabled to leave a permanent impress on science.

1. (with I. H. Orcutt). The Cutworm. Bull. South Dakota Exp., Sta., 18, 1890. pp. 29-36. 
2. (with I. H. Orcutt). Injurious Insects. Bull. South Dakota Exp. Stat., 22, 1891, pp. 77-118.

3. (with I. H. Orcutt). Report of the Department of Entomology. Bull. South Dakota Exp. Sta., 30, 1892, pp. 1-20.

4. A New Genus and Species of Tabanidæ. Psyche, March, 1892, pp. 236-237, figs.

5. The Systematic Position of the Diptera. Science, April, 1892, vol. 19, pp. 244-245.

6. New Species of Phora. Canadian Ent., vol. 24, June, 1892, pp. 142-146, figs.

7. Revision of the Genera Dolichopus and Hygroceleuthus. Kansas Univ. Quart., vol. 2, July, 1893, pp. 1-26, 1 pl.

8. The Dolichopodid Genus Liancalus Lw. Psyche, Dec., 1893, pp. 569-581.

9. New Genera and Species of Psilopinæ. Kansas Univ. Quart., vol. 2, 1893, pp. 47-50.

10. New Genera and Species of Dolichopodidæ. Kansas Univ. Quart., vol. 2, 1893, pp. 151-157.

11. Insecticides and Spraying. Bull. Idaho Exp. Sta., 7, 1894, $18 \mathrm{pp}$.

12. Courtship Among the Flies. American Naturalist, vol. 28, 1894, pp. 35-37.

13. The Tipulid Genera Bittacomorpha and Pedicia. Psyche, vol. 7, 1895, pp. 200-202, fig.

14. Family Dolichopodidæ in Williston's Manual of Diptera. Second ed., 1896, pp. 76-81.

15. On the Diptera of St. Vincent (Dolichopodidæ and Phoridæ). Trans. Ent. Soc., London, 1896, pp. 309-345, and $435-439$.

16. The Dipterous Genera Tachytrechus and Macellocerus. Trans. American Ent. Soc., March, 1896, vol. 23, pp. 81-84.

17. A Collection of Diptera from Indiana Caves. 21st Report Dept. Geol. and Nat'l. Resources of Indiana, 1896, (pub. May, 1897), pp. 187-188, figs. 
18. Report of Entomological Department. Annual Report Idaho Exp. Sta., 1898, pp. 167-176.

19. A Balloon-making Fly. American Naturalist, vol. 33, 1899, pp. 809-812, figs.

20. The San José Scale in Idaho. Bull. Idaho Exp. Sta., 16, 1899, $16 \mathrm{pp}$.

21. Goniops and other Synonyms. Ent. News, vol. 11, Sept., 1900, p. 531.

22. A Question of Nomenclature. Canadian Ent., vol. 32, 1900 , p. 318.

23. The Codling Moth. Bull. Idaho Exp. Sta., 21, 1900, pp. 97-112.

24. Synonymical Notiz. Wiener Ent. Zeit., vol. 20, 1901, p. 68.

25. Crude Petroleum. The Elm Louse. The Pear Leaf Blister Mite. Bull. Idaho Exp. Sta., 26, 1901, pp. 13-24.

26. Dolichopodidæ. Biologia Central-Americana, Dipt. I, Dec., 1901, pp. 333-366, 1 pl.

27. Dolichopodidæ of Grenada, W. I. Kansas Univ. Soc. Bull., vol. 1, March, 1902, pp. 75-94, 1 pl.

28. The Formation of Generic Names. Canadian Ent., 34, 1902 , p. 129.

29. Garry DeN. Hough, M. D., Biographical Sketch with Portrait. Ent. News, vol. 14, Oct., 1903, pp. 246249.

30. A Contribution to the Study of North American Dolichopodidæ. Trans. American Ent. Soc., vol. 30. 1904, pp. 269-286.

31. [several new species of Phoridæ] in Brues' Monograph of Phoridæ. Trans. American Ent. Soc., vol. 29, Jan., 1904, pp. 331-404.

32. The Genus Psilopus of Authors. Canadian Ent., vol. 36, Aug., 1904, pp. 246-247.

33. Grasshopper and Cricket Outbreaks in Idaho. Bull. Idaho Exp. Sta., 41, 1904, pp. 289-304. 
34. Winter Spraying for the Apple Aphis. Bull. Idaho Exp. Sta., 40, 1904, pp. 271-288.

35. Jocular Entomology. Canadian Ent., vol. 36, 1904, p. 82.

36. A Catalogue of North American Diptera. Smithsonian Miscellaneous Collections, No. 1444, vol. 46, 1905, pp. 1-680.

37. Baron Osten Sacken. Ent. News, vol. 17, Oct., 1906, pp. 269-272. (Obituary with portrait.)

38. The Dipterous Genus Calotarsa, with one New Species. Ent. News, vol. 17, April, 1906, pp. 123-127, 1 pl.

39. The Dipterous Genus Scellus, with one New Species. Ent. News, vol. 18, April, 1907, pp. 133-136.

40. Additions to my Catalogue of North American Diptera. Journ. New York Ent. Soc., vol. 15, March, 1907, pp. 1-9.

41. The Dipterous Family Helomyzidæ. Trans. American Ent. Soc., vol. 34, April, 1908, pp. 67-100, 2 pls.

42. Meigen's First Paper on Diptera. Canadian Ent., vol. 40, Oct., 1908, pp. 370-373.

43. Family Dolichopodidæ in Williston's Manual. Third Ed., 1908, pp. 228-235, 1 pl., 37 figs.

44. The Fruit-infecting Forms of the Dipterous Genus Rhagoletis, with one New Species. Canadian Ent., vol. 41, Feb., 1909, pp. 69-72, 1 pl.

45. A Decennial Confession. Canadian Ent., vol. 43, April, 1910, pp. 99-100.

46. The Genus Copestylum. Ent. News, vol. 21, May, 1910, pp. 222-225.

47. A Revision of the Dipterous Genus Hydrophorus. Psyche, vol. 18, April, 1911, pp. 45-70, 1 pl.

48. The Dipterous Genus Diostracus Lw. Psyche, vol. 18, April, 1911, pp. 70-72.

49. Larvæ of a Saturniid Moth used as food by California Indians. Journ. New York Ent. Soc., vol. 20, March, 1912, pp. 1-4, 1 pl. 
50. Flies of the Leptid Genus Atherix used as food by California Indians. Ent. News, vol. 23, April, 1912, pp. 159-163.

51. [Note on general non-acceptance in North America of Meigen's 1800 paper, and on Hendel's revolt against the Commission of Nomenclature] (without title). Canadian Ent., vol. 44, April, 1912, p. 104.

52. Note on Theronia fulvescens. Journ. Econ. Ent., vol. 5, Feb., 1912, pp. 87-88.

53. Two Western Species of Ephydra. Journ. New York Ent. Soc., vol. 20, June, 1912, pp. 100-103.

54. The Biology of Some Western Species of the Dipterous Genus Ephydra. Journ. New York Ent. Soc., vol. 20, June, 1912, pp. 77-99, 3 pls.

55. Collecting Notes from the Great Basin and Adjoining Territory. Ent. News, vol. 24, May, 1913, pp. 214221.

56. The North American Species of Lispa. Journ. New York Ent. Soc., vol. 21, June, 1913, pp. 126-146.

57. A New Leucopis with Yellow Antennæ. Journ. Econ. Ent., vol. 7, Oct., 1914, pp. 404-405.

58. Description of Sarcophaga kellyi. Journ. Agr. Research, vol. 2, Sept., 1914, pp. 443-445, 1 pl.

59. Results of 25 Years' Collecting in the Tachinidæ, with Notes on some common species. Ann. Ent. Soc. America, vol. 8, March, 1915, pp. 79-84.

60. The Economic Relations of the Sarcophagidæ. Journ. Econ. Ent., vol. 8, April, 1915, pp. 242-246.

61. New American Species of Asteia and Sigaloessa. Psyche, vol. 22, June, 1915, pp. 94-98, 2 figs.

62. The Deer Bot-Flies (Cephenomyia Latr.). Journ. New York Ent. Soc., vol. 23, June, 1915, pp. 145-150, 1 pl.

63. A New Sarcophaga parasitic on Allorhina nitida. Journ. New York Ent. Soc., vol. 8, Feb., 1915, pp. 151-152, fig.

64. The Dipterous Genus Symphoromyia in North America. Proc. United States Nat. Mus., vol. 49, July, 1916, pp. 113-142, with text figs. 
65. Sarcophaga and Allies in North America. Thomas Say Foundation, 1916, pp. 302, with 16 plates, index and historical sketch of the Foundation.

66. More Light on Myiophasia. Proc. Ent. Soc. Washington, vol. 18, 1916, pp. 98-100, figs.

67. Two New Canadian Diptera. Canadian Ent., vol. 48, Jan., 1916, pp. 20-23.

68. Notes on Diptera. Psyche, vol. 25, 1918, pp. 30-35.

69. Seasonal and Climatic Variation in Cerodonta. Ann. Ent. Soc. America, vol. 11, March, 1918, pp. 63-66.

70. The Anthomyid Genus Pogonomyia. Ent. News, vol. 29, May, 1918, pp. 179-185.

71. Two New Hydrotæas. Canadian Ent., vol. 50, Sept., 1918, pp. 311-314.

72. The Kelp-Flies of North America (Genus Fucellia, Family Anthomyiidæ). Proc. California Acad. Sci., vol. 8. Sept., 1918, pp. 157-179, 10 text figs.

73. New and Little Known Canadian Oscinidæ. Canadian Ent., vol. 50, Oct., 1918, pp. 336-344, figs.

74. Samuel Wendell Williston. Ent. News, vol. 29, Nov., 1918, pp. 322-327.

75. The Dipterous Genus Imitomyia Tns. (Himantostoma Lw.). Canadian Ent., vol. 51, 1919, p. 64.

76. Leiomyza in North America. Ent. News, vol. 30, May, 1919, pp. 137-141, fig.

77. Two New Genera of Anthomyidæ. Proc. Ent. Soc., Washington, vol. 21, May, 1919, pp. 106-109, fig.

78. Description of Hylemyia nidicola. Ann. Ent. Soc. America, vol. 12, 1919, pp. 380-381.

79. Samuel Wendell Williston, the Entomologist. Sigma Xi Quarterly, vol. 7, no. 1, 1919, pp. 19-21.

80. The European Frit Fly in North America. Journ. Agric. Research, vol. 18, Feb., 1920, pp. 451-472, 1 pl., figs.

81. The Muscoid Genera Pseudeuantha and Uramyia. Ins. Menst., vol. 9, March, 1921, pp. 83-92. 
82. The Dipterous Genus Dolichopus in North America. Bull. United States Nat. Mus., 116, March, 1921, 304 pp., 16 pls., 471 figs. (with M. C. Van Duzee and F. R. Cole.)

83. Coloradia pandora Blake, A Moth of which the Caterpillar is used as food by Mono Lake Indians. Ann. Ent. Soc. America, vol. 14, 1921, pp. 36-38.

84. The Division of Insects in the United States Nat. Mus. Ann. Rept. Smithsonian Inst., for 1919 (1921), pp. 367-379, 15 pls.

85. Two-winged Flies of the Genera Dolichopus and Hydrophorus collected in Alaska in 1921, with new Species of Dolichopus from North America and Hawaii. Proc. United States Nat. Mus., vol. 61, article 25, 1922, pp. 1-18.

86. A New Genus of Helomyzidæ. Bull. Brooklyn Ent. Soc., vol. 17, 1922, pp. 108-109.

87. A New Genus of Two-winged Fly with Mandible-like Labella. Proc. Ent. Soc. Washington, vol. 24, 1922, pp. 145-148.

88. The Neotropical Muscoid Genus Mesembrinella GiglioTos and other Testaceous Muscoid Flies. Proc. United States Nat. Mus., vol. 62, art. 11, Dec., 1922, pp. 1-24.

89. A New Tachinid Parasite of the Codling Moth. Ent. News, vol. 34, 1923, pp. 53-54.

90. Notes on the Dipterous Family Hippoboscidæ. Ins. Menst., vol. 11, 1923, pp. 75-79.

91. A New Sugar-cane Miner. Bull. Brooklyn Ent. Soc., vol. 18, 1923, pp. 22-23.

92. Two Asiatic Muscoid Flies parasitic on the so-called Japanese Beetle. Proc. United States Nat. Mus., vol. 63, art. 6, 1923, pp. 1-4.

93. New Genera of Two-winged Flies of the Subfamily Leptogastrinæ of the Family Asilidæ. Proc. United States Nat. Mus., vol. 62, art. 20, 1923, pp. 1-6.

94. A New Parasitic Fly Reared from the Bean Beetle. Proc. Ent. Soc. Washington, vol. 24, 1923, pp. 95-96. 
95. A New Genus and Species of Fly Reared from the Hoof of the Carabao. Philippine Journ. Sci., vol. 22, 1923, pp. 141-142.

96. Descriptions of Lantana Gall-Fly and Lantana SeedFly. Proc. Hawaii Ent. Soc., vol. 5, 1923, pp. 261263.

97. The Present Status of Coquillett's Hypochæta longicornis Schin. Proc. Ent. Soc. Washington, vol. 25, 1923, pp. 161-162.

98. The Genus Philornis, a Bird-infesting Group of Anthomyiidæ. Ann. Ent. Soc., America, vol. 16, 1923, pp. 304-309, figs.

99. The North American Species of Parasitic Two-winged Flies Belonging to the Genus Phorocera and Allied Genera. Proc. United States Nat. Mus., vol. 63, art. 17, Feb., 1924, pp. 1-90, fig.

100. The Muscoid Genus Genea in North America. Ent. News, vol. 35, 1924, pp. 210-214.

101. Notes on Some Types of American Muscoid Diptera in the Collection of the Vienna Natural History Miuseum. Ann. Ent. Soc. America, vol. 17, 1924, pp. 209-218.

102. A New Genus and Species of Two-winged Flies of the Family Chloropidæ injuring Manihot in Brazil. Proc. United States Nat. Mus., vol. 65, art. 21, 1924, pp. 1-2

103. Braula coeca in Maryland Apiaries. Journ. Washington Acad. Sci., vol. 14, 1924, p. 181.

104. Change of Preoccupied Names. Proc. Ent. Soc. Washington, vol. 26, 1924, p. 195.

105. Notes on North American Tachinidæ. Ins. Ins. Menst., vol. 12, 1924, pp. 145-149.

106. A New Tachinid Parasite of a Cocoanut Moth in South Asia. Proc. Ent. Soc. Washington, vol. 27, 1925, p. 13.

107. Notes on Some Types of American Muscoid Diptera in the Collection of the Vienna Natural History $\mathrm{Mu}$ seum. (second installment.) Ann. Ent. Soc. America, vol. 18, 1925, pp. 107-130. 
108. A New Leucopis from San Francisco. Pan Pacific Ent., vol. 1, 1925, p. 152.

109. New Diptera or Two-winged Flies in the United States National Museum. Proc. United States Nat. Mus., vol. 66,1925 , art. 18, pp. 1-36.

110. Two New Species of the Tachinid Genus Lixophaga, with Notes and Key. Proc. Ent. Soc. Washington, vol. 27, 1925, pp. 132-136.

111. The Muscoid Genus Pseudoservillia Tns. Ann. Mag. Nat. Hist., (9), vol. 16, 1925, p. 528.

112. Notes on Some Types of American Muscoid Flies in the Collection of the Vienna Natural History Museum. Ann. Ent. Soc. America, vol. 18, 1925, pp. 456-469, fig.

113. Occurrence of Morellia podagrica in North America. Ent. News, vol. 37, 1926, pp. 119-120.

114. On the Status of the Generic Name Anthrax Scopoli. Ins. Ins. Menst., vol. 14, 1926, pp. 12-15.

115. What is Oestrus nasalis Linnæus? Ibid., pp. 15-16.

116. North American Two-winged Flies of the Genus Cylindromyia Meigen (Ocyptera of Authors). Proc. United States Nat. Mus., vol. 68, art. 23, 1926, pp. 1-27, 1 pl.

117. Notes on Muscoid Flies with Retracted Hind Crossvein, with Key and Several New Genera and Species. Trans. American Ent. Soc., vol. 52, 1926, pp. 7-28.

118. Notes on the Metallic Green Tachinids allied to Gymnochæta, with Keys and one New Chinese Genus. Ins. Ins. Menst., vol. 14, 1926, pp. 51-58.

119. A new Genus of Heleomyzidæ from Chile, with Key to Genera. Ins. Ins. Menst., vol. 14, 1926, pp. 96-102.

120. Notes on Hypochæta and related Genera of Muscoid Flies. Proc. Ent. Soc. Washington, vol. 28, 1926, pp. 143-145.

121. American Two-winged Flies of the Genus Microphthalma Macquart, with Notes on Related Forms. Proc. United States Nat. Mus., vol. 69, art. 13, 1926, pp. 1-8. 
122. Descriptions of New and Little-known Diptera or Twowinged Flies. Proc. United States Nat. Mus., vol. 69 , art. 22, 1926, pp. 1-26.

123. A New Species of Oedematocera Reared from the Tropical Migratory Locust. Proc. Ent. Soc. Washington, vol. 29, 1927, pp. 17-18.

124. The Flies of the Western Mountains. Explorations and Field-Work of the Smithsonian Inst. of 1927 (Smithsonian Publication 2957), pp. 67-72, figs.

125. Chiromyia oppidana Scop. occurring in the United States. Ent. News, vol. 38, 1927, p. 79.

126. Notes on the Dexiid Genera Cordyligaster and Eucordyligaster. Proc. Washington Acad. Sci., vol. 17, 1927, pp. 84-86.

127. Notes on Muscoid Synonomy. Bull. Brooklyn Ent. Soc., vol. 22, 1927, pp. 18-25.

128. The Limitations of Taxonomy. Science, vol. 65, 1927, pp. 381-385.

129. Redescription of Types of American Muscoid Flies in the Collection of the Vienna Natural History $\mathrm{Mu}-$ seum, with Incidental Notes. Proc. United States Nat. Mus., vol. 72, art. 7, 1927, pp. 1-35, figs.

130. New Species of Two-winged Flies of the Family Cyrtidæ, with a New Genus from the Philippines. Proc. United States Nat. Mus., vol. 72, art. 9, 1927, pp. 1-4, figs.

131. The Dipterous Parasites of the Migratory Locust of Tropical America, Schistocerca paranensis Burm. Journ. Econ. Ent., vol. 20, 1927, pp. 588-593.

132. Note on Prosena sibirica Fab. and Related Forms. Ent. Mitteil., vol. 17, 1928, pp. 130-131.

133. A Revision of the American Parasitic Flies Belonging to the Genus Belvosia. Proc. United States Nat. Mus., vol. 73, art. 8, 1928, pp. 1-45.

134. Synonymic Notes on Diptera. Proc. Ent. Soc. Washington, vol. 30, 1928, pp. 41-45.

135. Three New Species of Two-winged Flies of the Family Bombyliidæ from India. Proc. United States Nat. Mus., vol. 74, art. 2, pp. 1-3, 1928. 
136. Notes on Synonymy of Diptera. Proc. Ent. Soc. Washington, vol. 30, 1928, pp. 142-145.

137. New Diptera or Two-winged Flies from South America. Proc. United States Nat. Mus., vol. 74, art. 1, 1928, pp. 1-25, 2 figs.

138. A New Species of Oedematocera with Notes on Schistocercophaga Townsend. Ent. News, vol. 39, 1928, pp. 301-304.

139. Five New Parasitic Flies Reared from Beetles in China and India. Proc. United States Nat. Mus., vol. 74, art. 8, 1928, pp. 1-7.

140. Notes on Synonomy of Diptera, No. 3. Proc. Ent. Soc. Washington, vol. 31, 1929, pp. 32-36.

141. Further Studies of Types of American Muscoid Flies in the Collection of the Vienna Natural History $\mathrm{Mu}-$ seum. Proc. United States Nat. Mus., vol. 74, art. 19, 1929, pp. 1-34, 2 figs.

142. Three New Acalyptrate Diptera. Proc. Ent. Soc. Washington, vol. 31, 1929, pp. 89-91.

143. New Genera and Species of Muscoid Flies. Proc. United States Nat. Mus., vol. 76, art. 15, 1929, pp. $1-13$.

144. Revision of the Two-winged Flies of the Genus Cœlopa in North America. Proc. United States Nat. Mus., vol. 76, art. 15, 1929, pp. 1-6.

145. A Revision of the Two-winged Flies of the Genus Prececidochares in North America. Proc. United States Nat. Mus., vol. 76, art. 2, 1929, pp. 1-13.

146. Notes on Synonomy of Diptera, No. 4. Proc. Ent. Soc. Washington, vol. 32, 1930, pp. 25-28.

147. Collecting Flies in Northern Europe. In Explorations and Field-work of the Smithsonian Institution in 1929 (Pub. No. 3060), 1930, pp. 113-118.

148. New Two-winged Flies of the Family Calliphoridæ from China. Proc. United States Nat. Mus., vol. 78, art. 1, 1930, pp. 1-5, 3 figs.

149. American Two-winged Flies of the Genus Stylogaster Macquart. Proc. United States Nat. Mus., vol. 78, art. 9, 1930, pp. 1-27. 
150. Notes on the Types of American Two-winged Flies of the Genus Sarcophaga and a Few Related Forms Described by the Early Authors. Proc. United States Nat. Mus., vol. 78, art. 12, 1930, pp. 1-39, 3 pls.

151. Collecting Flies in the West. Explorations and Fieldwork of the Smithsonian Institution in 1930, 1931, pp. 107-112.

152. Notes on Hippelates, with a New Brazilian Species. Proc. Ent. Soc. Washington, vol. 33, 1931, pp. 69-72.

153. Notes on Diptera, No. 5. Proc. Ent. Soc. Washington, vol. 33, 1931, pp. 116-121.

154. New Acalyptrate Diptera from the Pacific and Oriental Regions. Proc. Hawaiian Ent. Soc., vol. 7, 1931, pp. 395-399.

155. Notes on the Tachinid Genus Chætonodexodes, with one New Species. Ann. Mag. Nat. Hist., (10), vol. 8, 1931, pp. 205-207.

156. Notes on Francis Walker's Types of North American Flies of the Family Tachinidæ. Proc. United States Nat. Mus., vol. 80, art. 10, 1931, pp. 1-16.

157. North American Two-winged Flies of the Genus Spathimeigenia, with Descriptions of Five New Species. Proc. United States Nat. Mus., vol. 80, art. 11, 1931, pp. 1-10.

158. Review of Brues and Melander's Classification of Insects. Proc. Ent. Soc. Washington, vol. 34, 1932, pp. 45-46.

159. A New Genus and Two New Species of Muscoid Flies from Guatemala. Proc. Ent. Soc. Washington, vol. 34, 1932, pp. 23-25.

160. Records of Dipterous Insects of the Family Tachinidæ Reared by the late George Dimmock, with Description of One New Species and Notes on the Genus Anetia R. D. Proc. United States Nat. Mus., vol. 80, art. 20, 1932, pp. 1-8.

161. New Diptera, or Two-winged Flies, from America, Asia, and Java, with Additional Notes. Proc. United States Nat. Mus., vol. 81, art. 9, 1932, pp. 1-28, 1 pl. 
162. Notes on the Tachinid Genus Ceracia Rond., with a New Species from the Philippines. Proc. Ent. Soc. Washington, vol. 35, 1933, pp. 9-10.

163. Notes on the Tachinid Genus Elodia R. D., with three New Species of Elodia and Phorocera from Japan. Proc. Ent. Soc. Washington, vol. 35, 1933, pp. 19-23.

164. Further Comments on Meigen's 1800 Paper on Diptera. Ent. Monthly Mag., vol. 69, 1933, pp. 86-89.

165. Hunting Flies in the West. Explorations and Fieldwork of the Smithsonian Institution in 1932, 1933, pp. 33-36.

166. Two Reared Species of Tachinidæ from South America. Proc. Ent. Soc. Washington, vol. 35, 1933, pp. 170-173, fig.

167. Notes on Diptera, No. 6. Proc. Ent. Soc. Washington, vol. 35, 1933, pp. 165-170.

168. A Remarkable New Genus of Tachinidæ. Revista Ent., vol. 3, 1933, pp. 437-441, figs.

169. Correction to my Note on Meigen's 1800 Paper on Diptera. Ent. Monthly Mag., vol. 69, 1933, p. 255.

170. Types of Insects in the United States National Museum. Ent. News, vol. 45, 1934, p. 8.

171. Insects and Airplanes. Journ. Econ. Ent., vol. 27, 1934, p. 239.

172. Diptera of Patagonia and South Chile. Part 7, fascicle 1. Tachinidæ. British Museum, 1934, pp. 1-170, 21 figs.

173. Revista de Entomologia. Ent. News, vol. 45, 1934, pp. 51-52. 

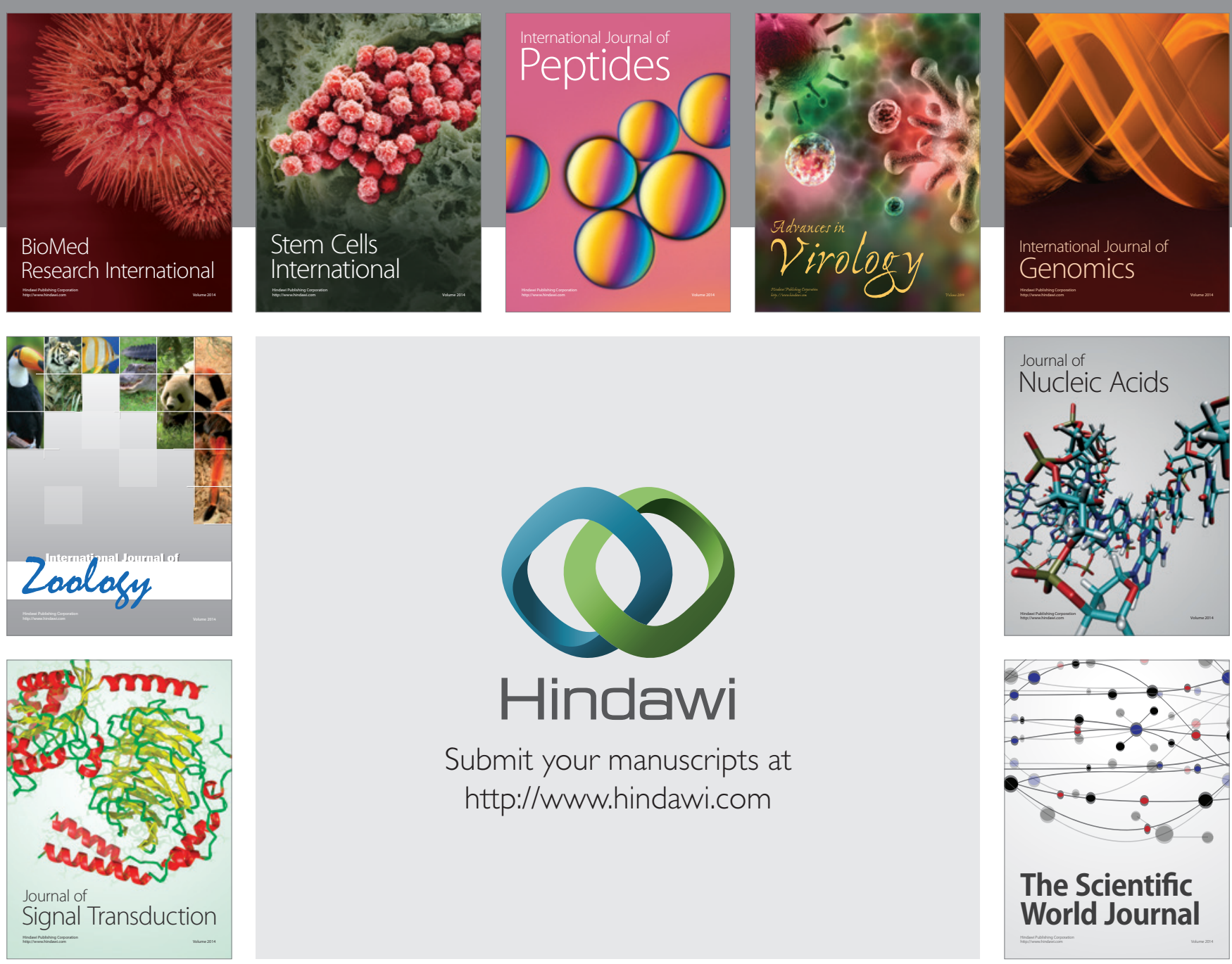

Submit your manuscripts at

http://www.hindawi.com
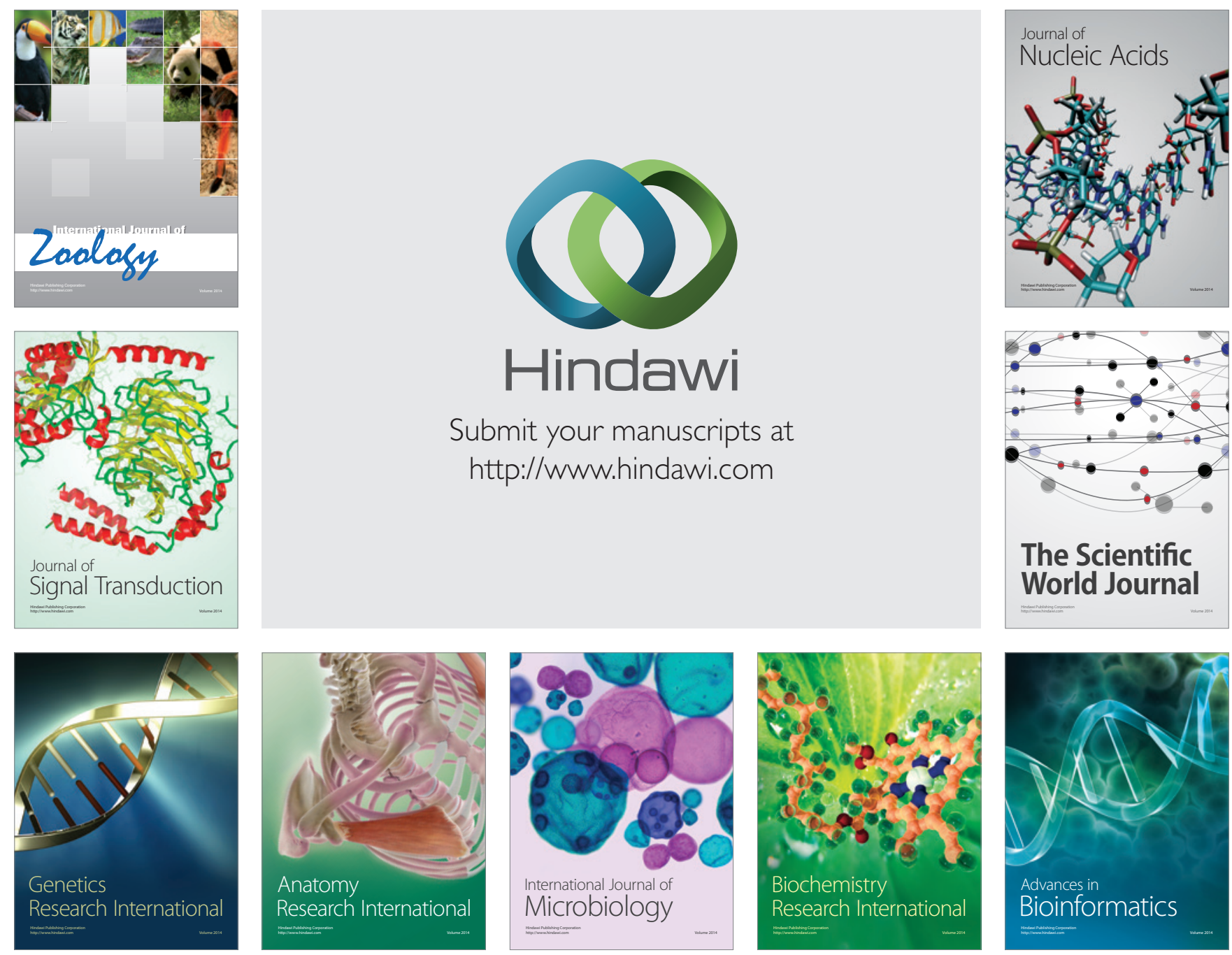

The Scientific World Journal
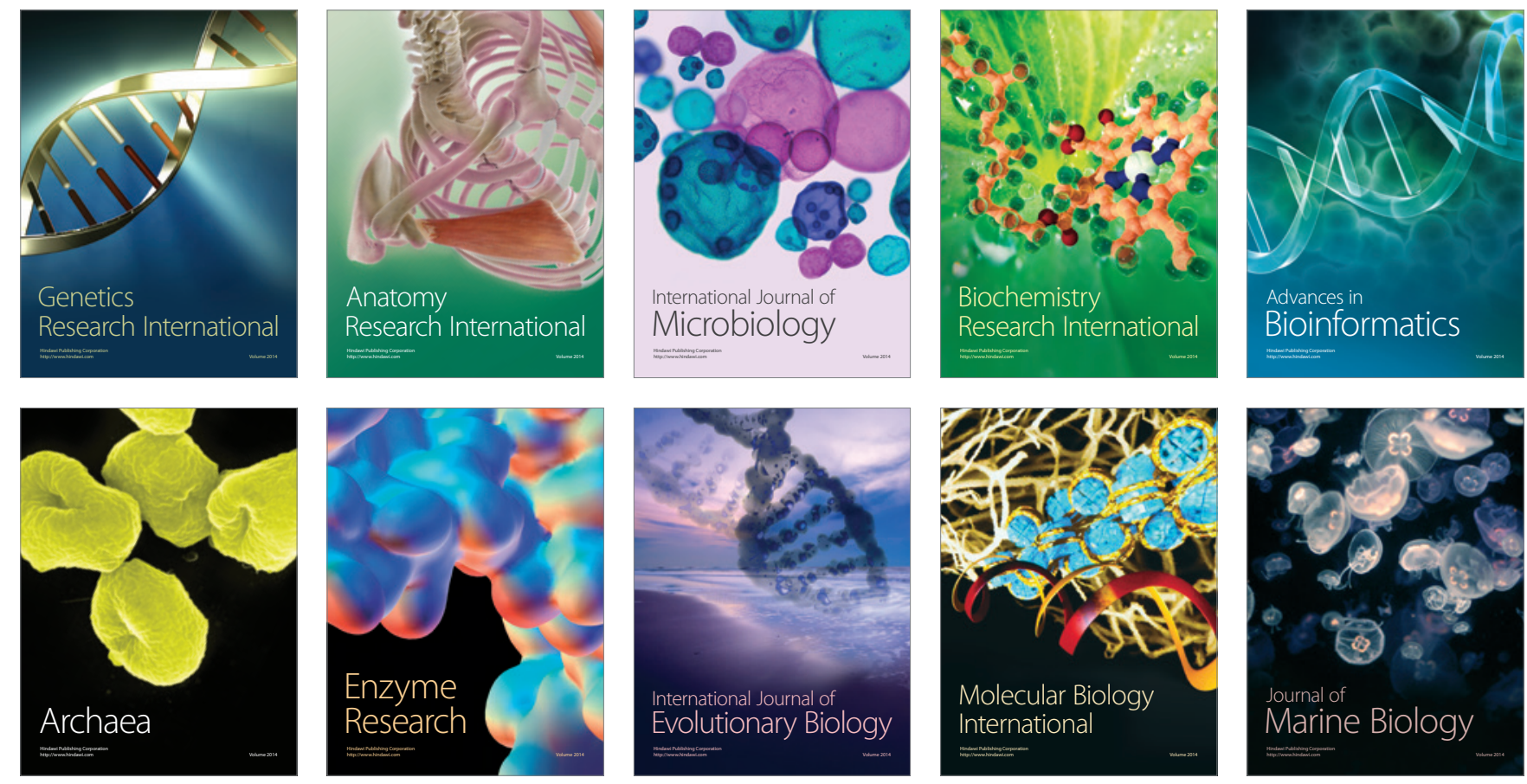